\title{
Over-the-Counter Monocyclic Non-Steroidal Anti-Inflammatory Drugs in Environment-Sources, Risks, Biodegradation
}

\author{
Ariel Marchlewicz • Urszula Guzik • \\ Danuta Wojcieszyńska
}

Received: 5 May 2015 / Accepted: 22 September 2015 /Published online: 30 September 2015

(C) The Author(s) 2015. This article is published with open access at Springerlink.com

\begin{abstract}
Recently, the increased use of monocyclic non-steroidal anti-inflammatory drugs has resulted in their presence in the environment. This may have potential negative effects on living organisms. The biotransformation mechanisms of monocyclic nonsteroidal anti-inflammatory drugs in the human body and in other mammals occur by hydroxylation and conjugation with glycine or glucuronic acid. Biotransformation/biodegradation of monocyclic non-steroidal anti-inflammatory drugs in the environment may be caused by fungal or bacterial microorganisms. Salicylic acid derivatives are degraded by catechol or gentisate as intermediates which are cleaved by dioxygenases. The key intermediate of the paracetamol degradation pathways is hydroquinone. Sometimes, after hydrolysis of this drug, 4aminophenol is formed, which is a dead-end metabolite. Ibuprofen is metabolized by hydroxylation or activation with CoA, resulting in the formation of isobutylocatechol. The aim of this work is to attempt to summarize the knowledge about environmental risk connected with the presence of over-the-counter antiinflammatory drugs, their sources and the biotransformation and/or biodegradation pathways of these drugs.
\end{abstract}

\footnotetext{
A. Marchlewicz • U. Guzik $(\bowtie) \cdot$ D. Wojcieszyńska Department of Biochemistry, Faculty of Biology and Environmental Protection, University of Silesia in Katowice, Jagiellonska 28, 40-032 Katowice, Poland e-mail: urszula.guzik@us.edu.pl
}

Keywords Monocyclic non-steroidal anti-inflammatory drugs $\cdot$ Toxicity $\cdot$ Biodegradation $\cdot$ Microorganisms

\section{Introduction}

In an age of high level care of human health, many pharmaceuticals are commonly used to cure or prevent diseases and other ailments, such as headache, muscle pain, or inflammatory conditions. Presently, over-thecounter drugs are very popular, especially over-thecounter monocyclic and polycyclic non-steroidal antiinflammatory drugs (NSAIDs). Among these drugs, the most popular and the most often used are monocyclic NSAIDs, such as ibuprofen, acetaminophen, and salicylic acid (and its derivatives, like mesalazine), due to their availability (Ziylan and Ince 2011). For example, the yearly intake of ibuprofen is up to $300 \mathrm{t}$ in Germany, $162 \mathrm{t}$ in England, and $58 \mathrm{t}$ in Poland (Sosnowska et al. 2009; Guzik et al. 2013a). In the USA during 2001-2005, about 29 billion doses of paracetamol in all forms were sold (Li et al. 2014). The high intake of these widely available drugs may lead to their or their metabolites' presence in the environment. In connection with the presence of NSAIDs in the environment, there is a risk of long-term exposure, causing chronic toxic effect in organisms living there. This may cause negative effects for living creatures and the accumulation of drugs or their metabolites in the food chain (Carlsson et al. 2006; Sosnowska et al. 2009). Current knowledge about the microbial metabolism of nonsteroidal anti-inflammatory drugs is still very little, and 
the fact that we can find them in the environment suggests that sewage treatment plants are not currently adapted to completely remove these drugs before they reach the environment. These drugs and their metabolites are found in wastewater influent and effluent from wastewater treatment plants. For example, in Germany, acetylsalicylic acid was detected in the sewage effluents at $0.22 \mu \mathrm{g} / \mathrm{L}$ (Heberer 2002) and paracetamol was detected in groundwater used as a source of public drinking water in California at $1.89 \mu \mathrm{g} / \mathrm{L}$ ( $\mathrm{Li}$ et al. 2014). Observed metabolites are formed as a result of the metabolism by activated sludge microorganisms or enter the treatment plants as the human body biotransformation products with municipal wastewater (Buser et al. 1999; Zwiener et al. 2002; Marco-Urrea et al. 2009; Ziylan and Ince 2011). The fate of medicines, including monocyclic NSAIDs, in the natural environmental is still less known. The main aim of this work is a compilation of the actual knowledge about sources and risks connected with the presence of monocyclic nonsteroidal anti-inflammatory drugs in the environment. Moreover, authors describe microbiological degradation of the three most widespread painkillers, antipyretic and anti-inflammatory and over-the-counter drugsacetylsalicylic acid, paracetamol, and ibuprofen.

\section{Sources of Pharmaceuticals in the Environment}

The development of modern analytical methods makes it possible to detect NSAIDs in the environment. Considering the high intake of drugs, it may be assumed that this has an impact on the presence of pharmaceuticals in wastewaters and surface waters. The main sources of drugs that reach the environment are excreted in nonmetabolized form or slightly modified, i.e., hydroxylated, conjugated, and disposed of through the toilet (Buser et al. 1999; Heberer 2002; Khan and Ongerth 2002; Zwiener et al. 2002; Metcalfe et al. 2004). Nearly half of respondents declared the disposal of medications in the household trash. That is why the presence of pharmaceuticals is expected in the landfill leachate or leachate-contaminated groundwater (Kuspis and Krenzelok 1996; Musson and Townsend 2009). Hospitals' wastewaters and discharges from pharmaceutical production also constitute a significant source of pharmaceuticals in the environment. In many countries, hospitals and pharmaceutical factories do not have separate wastewater treatment plants (WWTP); therefore, these contaminants pass into the general wastewater treatment system (Metcalfe et al. 2004). The burdened sewage flows into WWTPs, but not all NSAIDs are removed in biological sewage treatment with activated sludge. Drug detection in WWTP effluent confirmed inadequacy of wastewater treatment plants to completely removing these pollutants from sewage (Ternes 1998; Buser et al. 1999; Tixier et al. 2003; Lee et al. 2005; Gómez et al. 2007; Salgado et al. 2010). Consequently, this leads to the detection of drugs even in surface waters such as lakes or rivers (Winkler et al. 2001; Dębska et al. 2005; Roberts and Thomas 2006; Vieno et al. 2006; Togola and Budzinski 2008; Pailler et al. 2009). Additionally, Kolpin et al. (2004) observed an increased concentration of drugs in downstream, above places of outflows from WWTP.

\section{Environmental Risk of Monocyclic Non-Steroidal Anti-Inflammatory Drugs}

Although NSAIDs are observed in the environment in low concentrations, there is little known about the longterm effects of low concentrations of these drugs on living organisms. The most data about toxicity of ibuprofen, paracetamol, and acetylsalicylic acid are based on acute toxicity and short-term chronic toxicity tests (Table 1). In acute toxicity tests, high concentrations of substances that may result in unrealistic effects are usually used. In many cases, metabolites of drugs are not taken into account in toxicity tests; therefore, it is difficult to evaluate the real risk of NSAIDs and their metabolites on the environment (Webb 2004). MarcoUrrea et al. (2009), using Microtox toxicity test with Photobacterium phosphoreum as a tested organism, proved that hydroxylated derivatives of ibuprofen (which was also found in sewage and surface waters) are more toxic than the original compound. Pomati et al. (2004) showed that even microgram per liter concentration of ibuprofen can influence the growth of aquatic phototrophs. For example, Lemna minor exhibited inhibition of growth after 7-day exposure to low concentration of ibuprofen. Under these conditions, the little effect on abscisic acid production was also observed (Pomati et al. 2004; Brausch et al. 2012; Murdoch and Hay 2013). High sensitivity to ibuprofen was also found for phytoplankton. Depending on tested organisms, $\mathrm{EC}_{50}$ value was between 1 and $315 \mathrm{mg} / \mathrm{L}$ after $72-120-\mathrm{h}$ exposition to this drug (Brausch et al. 2012). 
Table 1 Toxicity of selected monocyclic NSAIDs

\begin{tabular}{|c|c|c|c|c|}
\hline Organism & Drug & Duration & Concentration (mg/L) & References \\
\hline Daphnia magna & ASA & $24 \mathrm{~h} \mathrm{EC}_{50}$ & 1468 & Lilius et al. (1994) \\
\hline Artemia salina & ASA & $24 \mathrm{~h} \mathrm{EC}_{50}$ & 382 & Calleja et al. (1994) \\
\hline Streptocephalus proboscideus & ASA & $24 \mathrm{~h} \mathrm{EC}_{50}$ & 178 & Calleja et al. (1994) \\
\hline Daphnia magna & ASA & $24 \mathrm{~h} \mathrm{EC}_{50}$ & 168 & Calleja et al. (1994) \\
\hline Brachionus calyciflorus & ASA & $24 \mathrm{~h} \mathrm{EC}_{50}$ & 141 & Calleja et al. (1994) \\
\hline Desmodesmus subspicatus & ASA & $24 \mathrm{~h} \mathrm{EC}_{50}$ & 106.7 & Cleuvers (2004) \\
\hline Daphnia magna & ASA & $24 \mathrm{~h} \mathrm{EC}_{50}$ & 88.1 & Cleuvers (2004) \\
\hline Daphnia magna & Ibuprofen & $48 \mathrm{~h} \mathrm{EC}_{50}$ & 51.4 & Han et al. (2010) \\
\hline Moina macrocopa & Ibuprofen & $48 \mathrm{~h} \mathrm{EC}_{50}$ & 72.6 & Han et al. (2010) \\
\hline Keletonema coststum & Ibuprofen & $96 \mathrm{~h} \mathrm{EC}_{50}$ & 7.1 & Halling-Sorensen et al. (1998) \\
\hline Daphnia magna & Ibuprofen & $48 \mathrm{~h} \mathrm{EC}_{50}$ & 9.06 & Halling-Sorensen et al. (1998) \\
\hline Lepomismacrochirus & Ibuprofen & $96 \mathrm{~h} \mathrm{EC}_{50}$ & 173 & Halling-Sorensen et al. (1998) \\
\hline Thamnocephalus platyurus & Ibuprofen & $24 \mathrm{~h} \mathrm{EC}_{50}$ & 19.59 & Kim et al. (2009) \\
\hline Oryzias latipes & Ibuprofen & $96 \mathrm{~h} \mathrm{EC}_{50}$ & $>100$ & Kim et al. (2009) \\
\hline Hydra attenuata & Ibuprofen & $96 \mathrm{~h} \mathrm{LC}_{50}$ & 22.36 & Quinn et al.(2008) \\
\hline Hydra attenuata & Ibuprofen & $96 \mathrm{~h} \mathrm{EC}_{50}$ & 1.65 & Quinn et al. (2008) \\
\hline Daphnia magna & Ibuprofen & $24 \mathrm{~h} \mathrm{EC}_{50}$ & 101.2 & Cleuvers (2004) \\
\hline Desmodesmus subspicatus & Ibuprofen & $24 \mathrm{~h} \mathrm{EC}_{50}$ & 343.2 & Cleuvers (2004) \\
\hline Artemia salina & Paracetamol & $24 \mathrm{~h} \mathrm{EC}_{50}$ & 577 & Calleja et al.(1994) \\
\hline Daphnia magna & Paracetamol & $24 \mathrm{~h} \mathrm{EC}_{50}$ & 55.5 & Calleja et al. (1994) \\
\hline Brachionus calyciflorus & Paracetamol & $24 \mathrm{~h} \mathrm{EC}_{50}$ & 5306 & Calleja et al. (1994) \\
\hline Daphnia magna & Paracetamol & $24 \mathrm{~h} \mathrm{EC}_{50}$ & 13 & Kühn et al. (1989)) \\
\hline Daphnia magna & Paracetamol & $48 \mathrm{~h} \mathrm{EC}_{50}$ & 9.2 & Kühn et al. (1989)) \\
\hline Daphnia magna & Paracetamol & $24 \mathrm{~h} \mathrm{EC}_{50}$ & 293 & Henschel et al. (1997) \\
\hline Daphnia magna & Paracetamol & $48 \mathrm{~h} \mathrm{EC}_{50}$ & 50 & Henschel et al. (1997) \\
\hline Brachydanio rerio & Paracetamol & $48 \mathrm{~h} \mathrm{EC}_{50}$ & 378 & Henschel et al. (1997) \\
\hline Scenedesmus subspicatus & Paracetamol & $24 \mathrm{~h} \mathrm{EC}_{50}$ & 134 & Henschel et al. (1997) \\
\hline Daphnia magna & SA & $24 \mathrm{~h} \mathrm{EC}_{50}$ & 230 & Wang and Lay (1989) \\
\hline Daphnia magna & SA & $\mathrm{EC}_{50}$ & 118 & Henschel et al. (1997) \\
\hline Brachydanio rerio & SA & $48 \mathrm{~h} \mathrm{EC}_{50}$ & 37 & Henschel et al. (1997) \\
\hline Scenedesmus subspicatus & SA & $72 \mathrm{~h} \mathrm{EC}_{50}$ & $>100$ & Henschel et al. (1997) \\
\hline
\end{tabular}

$S A$ salicylic acid, $A S A$ acetylsalicylic acid (aspirin), $N D$ no data

After 14 days of exposure of Daphnia magna to ibuprofen at concentration of 20,40 , and $80 \mathrm{mg} / \mathrm{L}$, significant effects in the total reproduction of daphnias were observed. Reproduction decreased with the increase of the drug concentration and totally stopped at $80 \mathrm{mg} / \mathrm{L}$. Additionally, the time of first reproduction was delayed in a concentration of $40 \mathrm{mg} / \mathrm{L}$. A low concentration of ibuprofen within the range of $1-100 \mathrm{ng} / \mathrm{L}$ caused a decrease in the activity of Gammarus pulex.
This is very important information, because this concentration range of ibuprofen corresponds more to the concentration in the environment (de Lange et al. 2006). Pounds et al. (2008) showed some chronic effects of ibuprofen on mollusc Planorbis carinatus in the drug concentrations $0.41,1.02,2.43$, and $5.36 \mathrm{mg} / \mathrm{L}$. In the lowest dose, the authors did not observe snails laying eggs. A dose of ibuprofen at $5.36 \mathrm{mg} / \mathrm{L}$ caused an inhibition of egg hatching (Pounds et al. 2008). Han 
et al. (2010) also observed a delay in Oryzias latipes egg hatching after exposure to $0.1 \mu \mathrm{g} / \mathrm{L}$ of ibuprofen. After 120 days of ibuprofen exposure, the survival of fish was also significantly lower when compared to the control population (Han et al. 2010). The obtained results are significant, because the drug concentration used in the experiment is observed in the environment (Dębska et al. 2005; Pailler et al. 2009).

Wu et al. (2012) described $p$-aminophenol as a major metabolite of paracetamol metabolism in microbes. 4Aminophenol is one of the most toxic phenols, which causes the kidney or the liver damage (Newton et al. 1982; Song and Chen 2001). Li et al. (2014) observed the appearance of $\mathrm{N}$-acetyl- $p$-benzoquinone imine (NAPQI) during biodegradation of acetaminophen in soil. Additionally, the increased sorption of paracetamol in soil biosolids was observed, which may cause a decrease of acetaminophen mineralization. Simultaneously, it may affect the half-life of drugs in the environment (Li et al. 2014).

$\mathrm{N}$-acetyl-p-benzoquinone imine is also one of the first phase metabolites of paracetamol detoxification in humans, excreted as a glutathione conjugate with urine (Tsikas et al. 2011; Li et al. 2014). It is defined as highly hepatotoxic (Bender and MacCrehan 2006; Hinson et al. 2010; Tsikas et al. 2011). Bender et al. (2004) suggest that NAPQI may be a potent inhibitor of human topoisomerase II $\alpha$.

Toxicological research conducted in the presence of high concentration of NSAIDs does not provide information about the influence of long-term exposure to low concentration of drugs. The answer to this question may be provided only by long-term research of many generations of aquatic organisms living in the presence of low drug concentration (Rzepa 2009).

\section{Acetylsalicylic Acid Biodegradation by Microorganisms}

In humans and animals, acetylsalicylic acid is immediately hydrolyzed to salicylic acid which can be removed from the body unchanged or in the form of conjugates with glycine (as a salicyluric acid) or with glucuronic acid, or hydroxylated at the C-5 position of the ring to gentisate (de Gaetano et al. 1985; Ingelman-Sundberg et al. 1991; Paterson et al. 2008). Apart from excretion from human and animal organisms, salicylic acid is a widespread molecule in plants. It plays a role in several physiological processes, like stomatal closure, flower induction, heat production and, most of all, its main function is defense against pathogen attack (Verberne et al. 2000). If we take this into consideration, it is not strange that in nature, there are effective salicylate degradation mechanisms. Many bacterial strains, like $M i$ crococcus, Sphingomonas, Amycolatopsis, Streptomyces, Pseudomonas, Alcaligenes, Pseudoramibacter, Rhodococcus (Chakrabarty 1972; Shamsuzzaman and Barnsley 1974; Haribabu et al. 1984; Grund et al. 1990; Grund et al. 1992; Civilini et al. 1999; Hintner et al. 2001; Ishiyama et al. 2004; Deveryshetty et al. 2007; Jouanneau et al. 2007; Silva et al. 2007; Lanfranconi et al. 2009) and fungi, like Sclerotinia, Trichosporon, Aspergillus, Fusarium, Rhodotorula, Cryptococcus (Anderson and Dagley 1980; Kuswandi and Roberts 1992; Middelhoven 1993; Iwasaki et al. 2009; Qi et al. 2012; Penn and Daniel 2013) are capable of degrading salicylate (Table 2) via a few catabolic pathways.

The strategy for degradation of aromatic structure comprises hydroxylation and cleavage of the aromatic ring. Hydroxylation into the dihydroxylated intermediates, the first step in the oxidative degradation of aromatic compounds, is catalyzed by oxygenases belonging to three groups: hydroxylating dioxygenases, activated-ring monooxygenases, or nonactivated-ring monooxygenases. As a result of hydroxylation, the key intermediates such as catechol, protocatechuic acid, hydroxyquinol, or gentisic acid are formed. These products are substrates for ring-cleaving dioxygenases. Salicylates are mainly transformed to catechol and gentisate, which are cleaved in the next step by dioxygenases from two groups - intradiol or extradiol (Guzik et al. 2013b; Guzik et al. 2014).

Two of the most important enzymes involved in salicylate decomposition are salicylate 1-hydroxylase and salicylate 5-hydroxylase (monooxygenases). Salicylate monooxygenases belong to one of the three groups of hydroxylating oxygenases-activated-ring monooxygenases (Wojcieszyńska et al. 2011). The general structure of these groups includes a threecomponent protein with separate functional units: reductase with a flavin cofactor, ferrodoxin with a Rieskietype iron-sulfur cluster [2Fe-2S] and hexamer-built $\alpha_{3} \beta_{3}$ terminal oxygenase with [2Fe-2S] a cluster and one nonheme iron(II) per $\alpha$ subunit (Mason and Cammack 1992; Bertini et al. 1996). These catalytic proteins are able to insert one atom of molecular oxygen into the structure of the aromatic ring, simultaneously 
Table 2 Microorganisms degrading selected monocyclic NSAIDs

\begin{tabular}{|c|c|c|c|}
\hline Strain & Drug & Concentration & References \\
\hline Pseudomonas putida $\mathrm{R} 1$ & SA & $10 \mathrm{mM}$ & Chakrabarty (1972) \\
\hline Acinetobacter lwoffii & ASA & $2.77 \mathrm{mM}$ & Grant (1971) \\
\hline Amycolatopsis rugosa DSM 43387 & SA & ND & Grund et al. (1990) \\
\hline Amycolatopsis rugosa DSM 43388 & SA & ND & Grund et al. (1990) \\
\hline Streptomyces niger DSM 40302 & SA & ND & Grund et al. (1990) \\
\hline Streptomyces olivaceiscloticus DSM 40595 & SA & ND & Grund et al. (1990) \\
\hline Rhodococcus sp. B4 & SA & ND & Grund et al. (1992) \\
\hline Pseudaminobacter salicylatoxidans B12 & SA & $5 \mathrm{mM}$ & Hintner et al. (2001) \\
\hline Pseudomonas sp. & SA & $3.5 \mathrm{mM}$ & Shamsuzzaman and Barnsley (1974) \\
\hline Pseudomonas aeruginosa $2 \mathrm{NR}$ & SA & ND & Civilini et al. (1999) \\
\hline Streptomyces sp. WA46 & SA & $7.24 \mathrm{mM}$ (on agar plate) & Ishiyama et al. (2004) \\
\hline Rhodococcus ruber IEGM 77 & ASA & $1.38-2.77 \mathrm{mM}$ & Ivshina et al. (2006) \\
\hline Pseudomonas sp. PPD & SA & ND & Deveryshetty et al. (2007) \\
\hline Alcaligenes sp. PPH & SA & ND & Deveryshetty et al. (2007) \\
\hline Sphingomonas sp. CHY-1 & SA & $0.5-1 \mathrm{mM}$ & Jouanneau et al. (2007) \\
\hline Pseudomonas fluorescens HK44 & SA & $0.18-1.45 \mathrm{mM}$ & Silva et al. (2007) \\
\hline Trichosporon cutaneum & SA & ND & Anderson and Dagley (1980) \\
\hline Aspergillus nidulans & SA & $10 \mathrm{mM}$ & Kuswandi and Roberts (1992) \\
\hline Fusarium graminearum & SA & $0.1-20 \mathrm{mM}$ & Qi et al. (2012) \\
\hline Sclerotinia sclerotiorum & SA & $1-10 \mathrm{mM}$ & Penn and Daniel (2013) \\
\hline Trichosporon moniliiforme WU-0401 & SA & $70 \mathrm{mM}$ & Iwasaki et al. (2009) \\
\hline Rhodococcus spp. & Paracetamol & $1.65-3.31 \mathrm{mM}$ & Ivshina et al. (2006) \\
\hline Delftia tsuruhatensis & Paracetamol & $0.007 \mathrm{mM}$ & de Gusseme et al. (2011) \\
\hline Pseudomonas aeruginosa & Paracetamol & $0.007 \mathrm{mM}$ & de Gusseme et al. (2011) \\
\hline Stenotrophomonas sp. f1 & Paracetamol & $2.64 \mathrm{mM}$ & Zhang et al. (2013) \\
\hline Pseudomonas sp. $\mathrm{f} 2$ & Paracetamol & $16.54 \mathrm{mM}$ & Zhang et al. (2013) \\
\hline Pseudomonas sp. fg-2 & Paracetamol & $13.23 \mathrm{mM}$ & Zhang et al. (2013) \\
\hline Penicillium sp. & Paracetamol & $0.66 \mathrm{mM}$ & Hart and Orr (1975) \\
\hline Filamentous fungi & Paracetamol & $0.99 \mathrm{mM}$ & Huang et al. (2006) \\
\hline Nocardia sp. NRRL 5646 & Ibuprofen & $4.85 \mathrm{mM}$ & Chen and Rosazza (1994) \\
\hline Sphingomonas Ibu-2 & Ibuprofen & $2.42 \mathrm{mM}$ & Murdoch and Hay (2005) \\
\hline Patulinobacter sp. I11 & Ibuprofen & $0.002 \mathrm{mM}$ & Almeida et al. (2013) \\
\hline Bjerkandera sp. R1 & Ibuprofen & $0.0049-0.0097 \mathrm{mM}$ & Rodarte-Morales et al. (2011) \\
\hline Bjerkandera adusta & Ibuprofen & $0.0049-0.0097 \mathrm{mM}$ & Rodarte-Morales et al. (2011) \\
\hline Phanerochaete chrysosporium & Ibuprofen & $0.0049-0.0097 \mathrm{mM}$ & Rodarte-Morales et al. (2011) \\
\hline Trametes versicolor & Ibuprofen & $0.097 \mathrm{mM}$ & Marco-Urrea et al. (2009) \\
\hline Irpex lacteus & Ibuprofen & $0.097 \mathrm{mM}$ & Marco-Urrea et al. (2009) \\
\hline Ganoderma lucidum & Ibuprofen & $0.097 \mathrm{mM}$ & Marco-Urrea et al. (2009) \\
\hline Phanerochaete chrysosporium & Ibuprofen & $0.097 \mathrm{mM}$ & Marco-Urrea et al. (2009) \\
\hline
\end{tabular}

$S A$ salicylic acid, $A S A$ acetylsalicylic acid (aspirin), $N D$ no data 
reducing the second oxygen atom to water. All salicylate hydroxylases need NADH to remain active. The oxidation of NADH is directly connected with FAD reduction (Katagiri et al. 1965; Sze and Dagley 1984; Grund et al. 1992; Suzuki et al. 1996; Fuenmayor et al. 1998; Balashova et al. 2001; Zhou et al. 2002; Jouanneau et al. 2007).

Chakrabarty (1972) and Deveryshetty et al. (2007) examined the ability of Pseudomonas putida R1 and Alcaligenes sp. PPH, respectively, to degrade salicylate. It was decomposed to catechol, the key intermediate, and further to 2-hydroxymuconic semialdehyde as a product of ring fission. Because of the significant activity of catechol 2,3-dioxygenase the authors concluded that $P$. putida R1 was capable of meta cleavage. On the other hand, decomposition of salicylate via catechol may also run via ortho cleavage with cis,cis-muconic acid as an aromatic ring cleavage product. Not only bacteria, such as Amycolatopsis, Streptomyces, or Pseudomonas, but also fungi, like Fusarium, Rhodotorula, Trichosporon, and Sclerotinia show that kind of catechol ring fission (Shamsuzzaman and Barnsley 1974; Anderson and Dagley 1980; Sze and Dagley 1984; Grund et al. 1990; Fuenmayor et al. 1998; Civilini et al. 1999; Ishiyama et al. 2004; Iwasaki et al. 2009; Qi et al. 2012; Penn and Daniel 2013).

Salicylate degradation may also lead via hydroxylation to gentisate. For example, this pathway was reported for Rhodococcus sp. B4 or Streptomyces sp. WA46 strains (Grund et al. 1992; Ishiyama et al. 2004). Enzymes engaged in this pathway need for their activity NADH, CoA and ATP as cofactors. Salicylate is converted to gentisate via salicylyl-CoA and gentisylCoA. In the first step, salicylyl-AMP ligase and probably salicylyl-CoA synthetase catalyze the formation of the thioester bond between salicylate and CoA and create salicylyl-CoA. The next step is the hydroxylation by salicylyl-CoA 5-hydroxylase with the formation of gentisyl-CoA. Hydrolysis to gentisate opens the way to ring cleavage by gentisate 1,2-dioxygenase to maleylpyruvate which leads to central metabolism. Civilini et al. (1999) showed the ability of Pseudomonas aeruginosa $2 \mathrm{NR}$ to convert salicylate into both intermediates, calechol, and gentisate.

Iwasaki et al. (2009) described a different model of decomposition of salicylate via catechol by yeast Trichosporon moniliiforme WU-0401. In their study, a non-oxidative way with phenol as an intermediate of salicylate degradation to catechol was presented.
Salicylate was immediately transformed to phenol with, simultaneously, decarboxylation, but without hydroxylation. Before that, phenol was hydroxylated to catechol and further cleaved in the ortho position.

Most bacteria degrade salicylate via oxidative decarboxylation to catechol or via hydroxylation to gentisate. Pseudaminobacter salicylatoxidans B12 is capable of direct ring cleavage using NADH-independent salicylate 1,2-dioxygenase forming 2-oxohepta-3,5dienedioic acid as an aliphatic product (Hintner et al. 2001).

\section{Microbial Degradation and Transformation of Paracetamol}

Paracetamol (acetaminophen) is an analgesic and antipyretic drug, and is one of the most popular over-thecounter drugs (Chandrasekharan et al. 2002). Acetaminophen is in most cases metabolized in the liver via three metabolic pathways. Most of this drug is secreted as conjugates with glucuronic acid $(60 \%)$ or sulfate $(30 \%)$ (Herd et al. 1991). A small amount of the medicine ( $8 \%$ ) may be dehydrogenated by cytochrome P450 to a toxic derivative $\mathrm{N}$-acetyl- $p$-benzoquinone imine (Bock et al. 1987; Herd et al. 1991; Bessems and Vermeulen 2001). Nevertheless, knowledge about the further fate of acetaminophen in the environment is still limited. Hart and Orr (1975) obtained Penicillium sp. able to transform paracetamol to 4-aminophenol and acetate, probably with the use of aryl acylamidase. 4Aminophenol is a dead-end metabolite (Fig. 1). Ivshina et al. (2006) reported the ability of Rhodococcus strains to degrade paracetamol with three detectable metabolites: 4-aminophenol, catechol, and hydroquinone. 4Aminophenol may undergo oxidative deamination to hydroquinone (de Gusseme et al. 2011; Wei et al. 2011; Wu et al. 2012; Zhang et al. 2013). Further degradation of 1,4-hydroxybenzene could proceed in two ways. Hydroquinone may be directly cleaved by hydroquinone 1,2-dioxygenase with 4-hydroxymuconic semialdehyde as an aliphatic product (Jain et al. 1994; Rieble et al. 1994; Daubaras et al. 1996). This pathway was also suggested by de Gusseme et al. (2011), which observed degradation of hydroquinone by Delftia tsuruhatensis and Pseudomonas aeruginosa. The second way was described by Takenaka et al. (2003). These authors showed that Burkholderia sp. AK-4 converted 4-aminophenol to 1,4-hydroxybenzene and further to 
1,2,4-trihydroxybenzene. Then 1,2,4-trihydroxybenzene was cleaved by hydroxyhydroquinone 1,2-dioxygenase to maleylacetic acid, which is introduced to the basic metabolism (Mason and Cammack 1992; Chauhan et al. 2000; Miyauchi et al. 1999; Moonen et al. 2008; Kolvenbach et al. 2011) (Fig. 1). Zhang et al. (2013) described the conversion of acetaminophen to hydroquinone, which was next transformed to an aliphatic product hexa-3-enedioic acid. Unfortunately, the authors did not determine the enzyme engaged in ring cleavage. However, it seems that hexa-3-enedioic acid was a product of aromatic ring fission or, if not, it that means some intermediate metabolites between aromatic and aliphatic compounds were passed over. Hexa-3-enedioic acid is similar to muconic acid - a product of ortho ring cleavage of catechol, but the authors did not find catechol in the studied samples. Based on reported intermediates a primary pathway of acetaminophen degradation could be proposed. The mechanism may be based on cutting off two carbon atoms in the form of formic acid (Fig. 1) (Zhang et al. 2013).
Furthermore, Huang et al. (2006) described the formation of glucoside conjugates with paracetamol by soil filamentous fungi via $\mathrm{O}-$ and $\mathrm{N}$-linkages. This is a similar way to the human detoxication routes of xenobiotics in phase II of detoxication (Halling-Sorensen et al. 1998).

In 2014, Li et al. described degradation pathway of paracetamol in soil microorganisms. It was shown that in the first step, aromatic ring of paracetamol is hydroxylated to 3-hydroxyacetaminophen, oxygenated to $\mathrm{N}$-acetyl- $p$-benzoquinone imine, or methylated to $p$-acetanisidide. It is suggested that cytochrome P-450 may be engaged in these processes. $\mathrm{N}$-acetyl-p-benzoquinone imine is then metabolized to 1,4-benzoquinone which is more stable and critical toxic metabolite. $p$-Acetanisidide is transformed to 4-methoxyphenol and in the next step to the 1,4-dimethoxybenzene. The presence of 2hexenoic acid in the soil extract suggests the cleavage of the aromatic ring of paracetamol $(\mathrm{Li}$ et al. 2014).

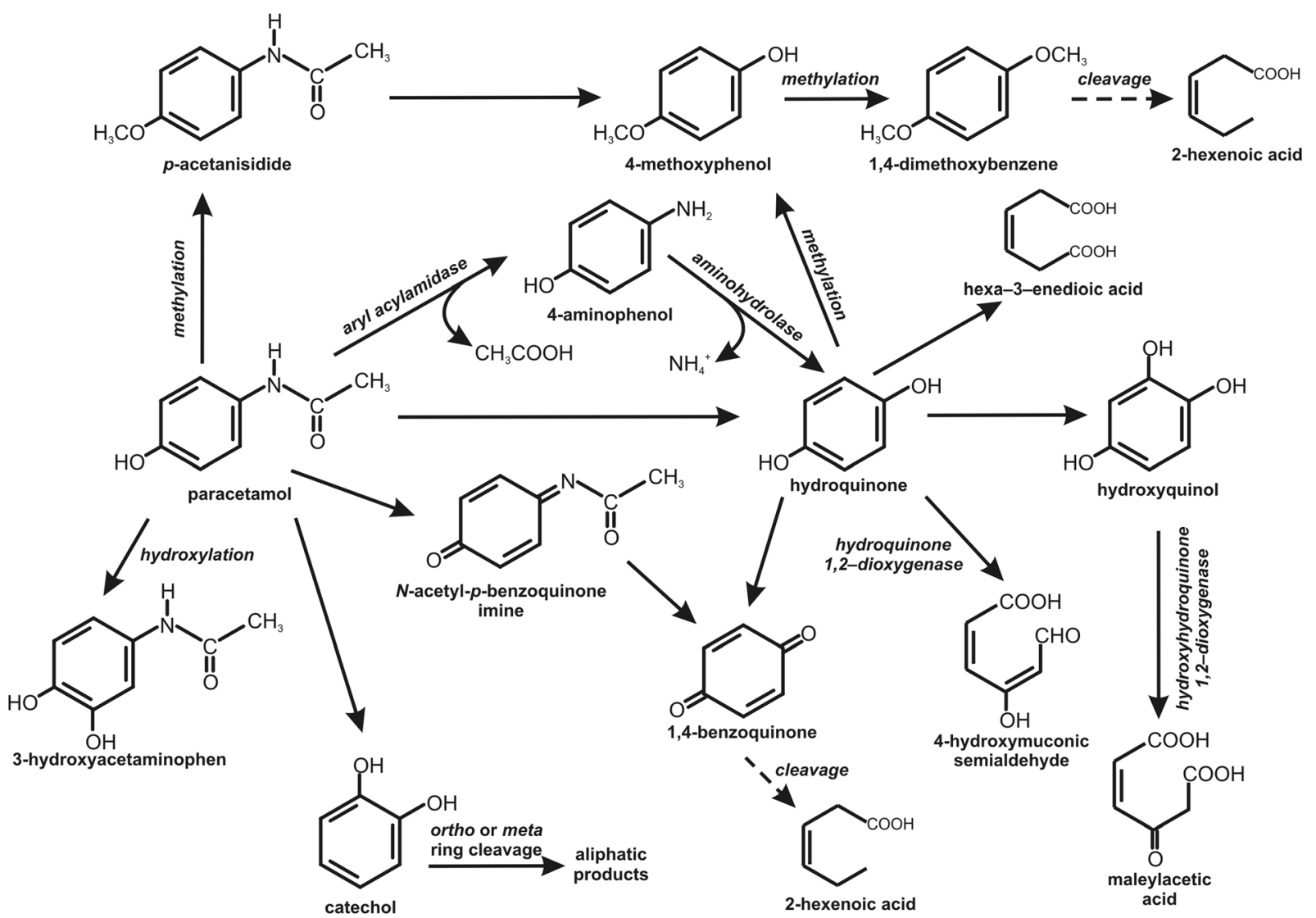

Fig. 1 Biotransformation of paracetamol (Hart and Orr 1975; Takenaka et al. 2003; Kolvenbach et al. 2011; Wu et al. 2012; Zhang et al. 2013; Guzik et al. 2014; Li et al. 2014) 


\section{Biodegradation/Biotransformation of Ibuprofen}

Ibuprofen (2-(4-(2-methylpropyl)phenyl)propanoic acid) is one of the most popular and commonly used non-steroidal anti-inflammatory drugs. This makes it the third most popular drug in the world. Ibuprofen is also one of the dominating medicines present in sewage because of its relatively high therapeutic dose (600$1200 \mathrm{mg}$ per day), and significant levels are excreted from the human body (even 70-80 \%). This drug may be secreted as an unchanged molecule or as an unchanged molecule in conjugation with glucuronide (product of the second phase of detoxication that may be hydrolyzed in the environment) or as a few metabolites: hydroxyibuprofen (two isomers), carboxyibuprofen, and carboxyhydratropic acid (Halling-Sorensen et al. 1998; Buser et al. 1999; Zwiener et al. 2002). Nonetheless, little is still known about the environmental metabolism of ibuprofen, whose concentration in the environment ranges from nanograms per liter to micrograms per liter (Calamari et al. 2003; Bendz et al. 2005; Tauxe-Wuersch et al. 2005; Nakada et al. 2006; Roberts and Thomas 2006; Gómez et al. 2007; Lin et al. 2009; Pailler et al. 2009).

Many reports describe only the initial steps of ibuprofen transformation. Rodarte-Morales et al. (2011) used three species of ligninolytic fungi: Bjerkandera sp. R1, Bjerkandera adusta, and Phanerochaete chrysosporium to check their ability to degrade pharmaceuticals, including ibuprofen (Table 2). They reported a rapid decrease of ibuprofen in growth medium, explaining that fact by degradation of the drug. However, these authors did not search for intermediates occurring in the degradation process, and they noted only the loss of the parent compound. It may be suggested that ibuprofen was not completely mineralized. Trametes versicolor, Irpex lacteus, Ganoderma lucidum, and P. chrysosporium are fungi capable of degrading ibuprofen (Marco-Urrea et al. 2009). All of them, excluding $P$. chrysosporium, degraded $10 \mathrm{mg} / \mathrm{L}$ ibuprofen to non-detectable levels. $P$. chrysosporium showed the lowest degradation level, between 70 and $88 \%$. Simultaneously, it should be noted that the authors tested the in vitro activity of laccase (also with laccase mediators) and manganese peroxidase. Moreover, they used inhibitors of the cytochrome P-450 complex to analyze the participation of these enzymes in ibuprofen degradation. In all cases, the researchers did not observe the contribution of the examined enzymes in the metabolism of ibuprofen. It may be suggested that the metabolism of ibuprofen could run through another pathway. The major metabolites which were found were hydroxylated in the isopropyl chain from ibuprofen-1- and 2-hydroxyibuprofen after the first hours of the experiment, and 1,2dihydroxyibuprofen as a final metabolite after 7 days of cultivation (Fig. 2). Hydroxylated and carboxylated derivatives are frequent in the microbial metabolism (Zwiener et al. 2002; Quintana et al. 2005). It is noteworthy that ibuprofen derivatives are more toxic than the parent compound and may accumulate in the environment (Marco-Urrea et al. 2009). Despite low concentrations of these compounds in the ecosystem, they may be hazardous. However, the long-term effects of the organism exposure to this drug cannot be defined (Perry
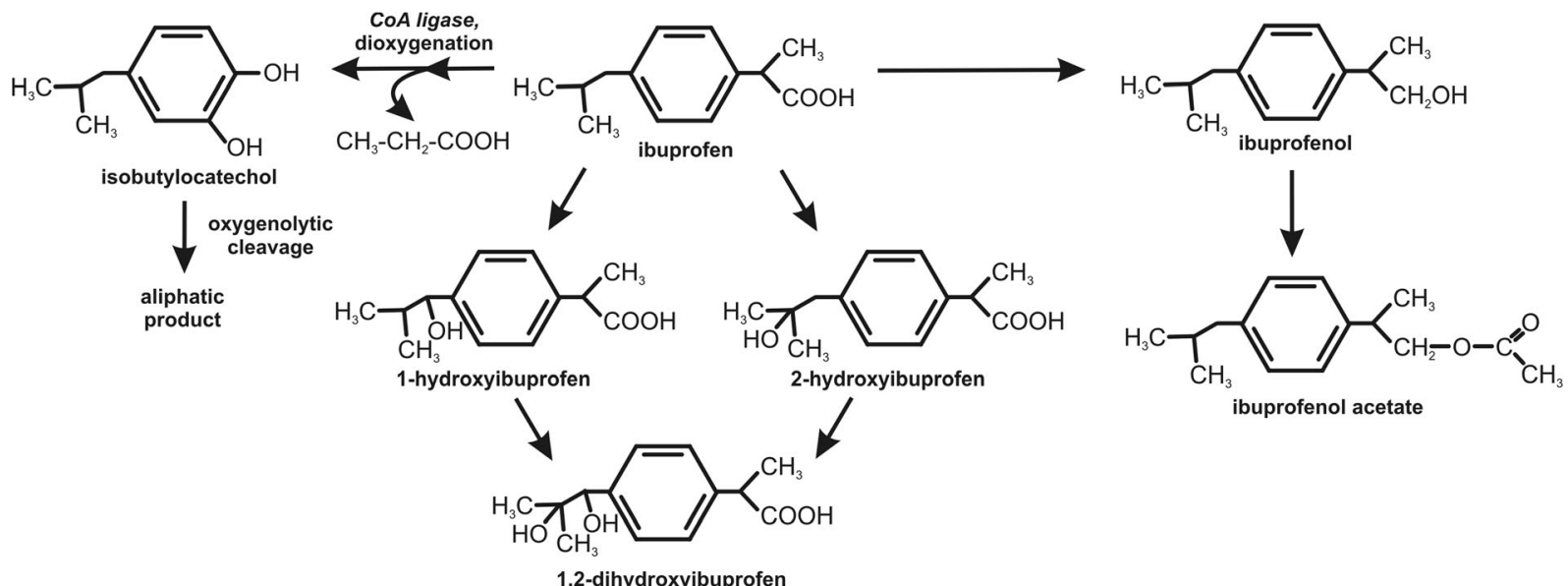

Fig. 2 Microbiological transformation of ibuprofen (Chen and Rosazza 1994; Murdoch and Hay 2005; Quintana et al. 2005; Guzik et al. 2014) 
and Zylstra 2007). On the basis of European Union law, Cleuvers (2004) did not classify ibuprofen as toxic to aquatic organisms. However, a study with Daphnia magna and green algae showed that ibuprofen may be a toxic factor, especially in the presence of other drugs. This study informs about the effect of high-dose toxicity in short time exposure. In the environment, pharmaceuticals are not in high concentrations, so greater emphasis should be put on studies on the chronic toxicity of drugs (Cleuvers 2004).

During the degradation of ibuprofen by the lignolytic bacterium Nocardia sp. NRRL 5646, two metabolites, ibuprofenol and ibuprofenol acetate, were observed (Fig. 2). These products underwent further mineralization (Chen and Rosazza 1994).

Murdoch and Hay $(2005,2013)$ characterized one of the most completed ibuprofen degradation pathways in Sphingomonas Ibu-2 bacteria, capable of using ibuprofen as a source of carbon and energy. Based on genetic analyses, they proposed five-gene cluster (ipf $A B D E F$ ), coding enzymes putatively involved in ibuprofen catabolism. Two of these genes (ipfA, ipfB) were very similar to genes coding two subunits of dioxygenases; the third gene was identified as a gene coding enzyme for the removal/addition of acyl groups - acyl-CoA synthetase (IpfD); the fourth one (ipfF) was described as a coenzyme A ligase gene; and for the gene ipfE, no function was found. Two additional genes ipfH and ipfI encode ferredoxin reductase and ferredoxin components of an aromatic dioxygenase system, respectively (Murdoch and Hay 2013). As the first step in the decomposition of ibuprofen by strain Ibu-2, thioesterification with coenzyme A with the participation of coenzyme A ligase was suggested. Removal of the propionic acid chain and dioxygenation reaction led to isobutylocatechol formation. This compound undergoes oxygenolytic cleavage (Murdoch and Hay 2005; Murdoch and Hay 2013) (Fig. 2). Ibuprofen biotransformation by Variovorax Ibu-1 occurs with trihydroxyibuprofen as a metabolite. This compound may be a dead-end metabolite or is substrate to the meta-ring fission reaction (Murdoch and Hay 2015).

Patulinobacter sp. I11 did not grow with ibuprofen as the only source of carbon and energy. However, degradation of ibuprofen was observed in the presence of yeast extract and tryptone. This suggests that ibuprofen could not induce the expression of enzymes responsible for its decomposition. In the bacterial genome, homologous genes were found coding enzymes potentially involved in ibuprofen decomposition, such as acyl-CoA synthetase, a protein containing a Rieske-like (2Fe-2S) iron-sulfur cluster (dioxygenase-like protein), and enoyl-CoA hydratase/isomerase (Almeida et al. 2013).

\section{Conclusion}

The occurrence of micropollutants in the environment, such as non-steroidal anti-inflammatory drugs, is a relatively new problem. The presence of these drugs in the environment poses a risk of long-term exposure, causing chronic toxic effects for organisms. Although the salicylic acid pathway is very well described, little is known about the biotransformation/biodegradation of other non-steroidal anti-inflammatory drugs such as ibuprofen or paracetamol. Paracetamol degradation pathways lead through hydroquinone as a key intermediate, whereas ibuprofen is metabolized by hydroxylation or activation with CoA. However, sometimes biotransformation of monocyclic NSAIDs leads to the accumulation of intermediates more toxic than the parent compounds. An understanding the drug mineralization processes is key to creating commercially available solutions for this increasing problem.

\section{Compliance with Ethical Standards}

Funding This work was financed by the National Science Centre (Poland), granted on the basis of decision DEC-2013/09/B/ NZ9/00244.

Conflict of Interest The authors declare that they have no conflict of interest.

Open Access This article is distributed under the terms of the Creative Commons Attribution 4.0 International License (http:// creativecommons.org/licenses/by/4.0/), which permits unrestricted use, distribution, and reproduction in any medium, provided you give appropriate credit to the original author(s) and the source, provide a link to the Creative Commons license, and indicate if changes were made.

\section{References}

Almeida, B., Kjeldal, H., Lolas, I., Knudsen, A. D., Carvalho, G., Nielsen, K. L., Barreto Crespo, M. T., Stensballe, A., \& Nielsen, J. L. (2013). Quantitative proteomic analysis of ibuprofen-degrading Patulibacter sp. strain I11. Biodegradation, 24, 615-630. 
Anderson, J. J., \& Dagley, S. (1980). Catabolism of aromatic acids in Trichosporon cutaneum. Journal of Bacteriology, 141(2), 534-543.

Balashova, N. V., Stolz, A., Knackmuss, H. J., Kosheleva, I. A., Naumov, A. V., \& Boronin, A. M. (2001). Purification and characterization of a salicylate hydroxylase involved in 1hydroxy-2-naphthoic acid hydroxylation from the naphthalene and phenanthrene-degrading bacterial strain Pseudomonas putida BS202-P1. Biodegradation, 12, 179188.

Bender, M., \& MacCrehan, W. A. (2006). Transformation of acetaminophen by chlorination produces the toxicants $1,4-$ benzoquinone and $\mathrm{N}$-acetyl-p-benzoquinone imine. Environmental Science and Technology, 40, 516-522.

Bender, R. P., Lindsey, R. H., Burden, D. A., \& Osheroff, N. (2004). N-Acetyl-p-benzoquinone imine, the toxic metabolite of acetaminophen, is a topoisomerase II poison. Biochemistry, 43, 3731-3739.

Bendz, D., Paxéus, N. A., Ginn, T. R., \& Loge, F. J. (2005). Occurrence and fate of pharmaceutically active compounds in the environment, a case study: Höje river in Sweden. Journal of Hazardous Materials, 122, 195-204.

Bertini, I., Cremonini, M. A., Ferretti, S., Lozzi, I., Luchinat, C., \& Viezzoli, M. S. (1996). Arene hydroxylases: metalloenzymes catalysing dioxygenation of aromatic compounds. Coordination Chemistry Review, 151, 145-160.

Bessems, J. G. M., \& Vermeulen, N. P. E. (2001). Paracetamol (acetaminophen)-induced toxicity: molecular and biochemical mechanisms, analogues and protective approaches. Critical Review in Toxicology, 31(1), 55-138.

Bock, K. W., Wiltfang, J., Blume, R., Ullrich, D., \& Bircher, J. (1987). Paracetamol as a test drug to determine glucuronide formation in man. Effects of inducers and of smoking. European Journal of Clinical Pharmacology, 31, 677-683.

Brausch, J. M., Connors, K. A., Brooks, B. W., \& Rand, G. M. (2012). Human pharmaceuticals in the aquatic environment: a review of recent toxicological studies and consideration for toxicity testing. Reviews of Environmental Contamination and Toxicology, 218, 1-99.

Buser, H. R., Poiger, T., \& Muller, M. D. (1999). Occurrence and environmental behavior of the chiral pharmaceutical drug ibuprofen in surface waters and in wastewater. Environmental Science and Technology, 33, 2529-2535.

Calamari, D., Zuccato, E., Castiglioni, S., Bagnati, R., \& Fanelli, R. (2003). Strategic survey of therapeutic drugs in the Rivers Po and Lambro in Northern Italy. Environmental Science and Technology, 37, 1241-1248.

Calleja, M. C., Personne, G., \& Geladi, P. (1994). Comparative acute toxicity of the first 50 multicentre evaluation of in vitro cytotoxicity chemicals to aquatic non vertebrates. Archives of Environmental Contamination and Toxicology, 26, 69-78.

Carlsson, C., Johansson, A. K., Alvan, G., Bergman, K., \& Kühler, T. (2006). Are pharmaceuticals potent environmental pollutants? Part I: Environmental risk assessments of selected active pharmaceutical ingredients. Science of the Total Environment, 364, 67-87.

Chakrabarty, A. M. (1972). Genetic basis of the biodegradation of salicylate in Pseudomonas. Journal of Bacteriology, 112(2), 815-822.

Chandrasekharan, N. V., Dai, H., Roos, K. L. T., Evanson, N. K., Tomsik, J., Elton, T. S., \& Simmons, D. L. (2002). COX-3, a cyclooxygenase-1 variant inhibited by acetaminophen and other analgesic/antipyretic drugs: cloning, structure, and expression. Proceedings of the National Academy of Sciences, 99(21), 13926-13931.

Chauhan, A., Samanta, S. K., \& Jain, R. K. (2000). Degradation of 4-nitrocatechol by Burkholderia cepacia: a plasmid-encoded novel pathway. Journal of Applied Microbiology, 88(5), 764 772.

Chen, Y., \& Rosazza, J. P. N. (1994). Microbial transformation of ibuprofen by a Nocardia species. Applied and Environmental Microbiology, 60, 1292-1296.

Civilini, M., de Bertoldi, M., \& Tell, G. (1999). Molecular characterization of Pseudomonas aeruginosa 2NR degrading naphthalene. Letters in Applied Microbiology, 29, 181-186.

Cleuvers, M. (2004). Mixture toxicity of the anti-inflammatory drugs diclofenac, ibuprofen, naproxen, and acetylsalicylic acid. Ecotoxicology and Environmental Safety, 59, 309-315.

Daubaras, D. L., Saido, K., \& Chakrabarty, A. M. (1996). Purification of hydroxyquinol 1,2-dioxygenase and maleylacetate reductase: the lower pathway of 2,4,5trichlorophenoxyacetic acid metabolism by Burkholderia cepacia AC1100. Applied and Environmental Microbiology, 62(11), 4276-4279.

de Gaetano, G., Cerletti, C., Dejana, E., \& Latini, R. (1985). Pharmacology of platelet inhibition in humans: implications of the salicylate-aspirin interaction. Circulation, 72(6), $1185-1193$

de Gusseme, B., Vanhaecke, L., Verstraete, W., \& Boon, N. (2011). Degradation of acetaminophen by Delftia tsuruhatensis and Pseudomonas aeruginosa in a membrane bioreactor. Water Research, 45, 1829-1837.

de Lange, H. J., Noordoven, W., Murk, A. J., Lurling, M., \& Peeters, E. T. H. M. (2006). Behavioural responses of Gammarus pulex (Crustacea, Amphipoda) to low concentrations of pharmaceuticals. Aquatic Toxicology, 78, 209-216.

Dębska, J., Kot-Wasik, A., \& Namiesnik, J. (2005). Determination of nonsteroidal anti-inflammatory drugs in water samples using liquid chromatography coupled with diode-array detector and mass spectrometry. Journal of Separation Science, 28, 2419-2426.

Deveryshetty, J., Suvekbala, V., Varadamshetty, G., \& Phale, P. S. (2007). Metabolismof 2-, 3- and 4-hydroxybenzoates by soil isolates Alcaligenes sp. strain PPH and Pseudomonas sp. strain PPD. FEMS Microbiology Letters, 268, 59-66.

Fuenmayor, S. L., Wild, M., Boyes, A. L., \& Williams, P. A. (1998). A gene cluster encoding steps in conversion of naphthalene to gentisate in Pseudomonas sp. strain U2. Journal of Bacteriology, 180(9), 2522-2530.

Gómez, M. J., Martínez Bueno, M. J., Lacorte, S., FernándezAlba, A. R., \& Agüera, A. (2007). Pilot survey monitoring pharmaceuticals and related compounds in a sewage treatment plant located on the Mediterranean coast. Chemosphere, 66, 993-1002.

Grant, D. J. W. (1971). Degradation of acetylsalicylic acid by a strain of Acinetobacter lwoffii. Journal of Applied Bacteriology, 34, 689-698.

Grund, E., Denecke, B., \& Eichenlaub, R. (1992). Naphthalene degradation via salicylate and gentisate by Rhodococcus sp. strain B4. Applied and Environmental Microbiology, 58(6), 1874-1877. 
Grund, E., Knorr, C., \& Eichenlaub, R. (1990). Catabolism of benzoate and monohydroxylated benzoates by Amycolatopsis and Streptomyces spp. Applied and Environmental Microbiology, 56(5), 1459-1464.

Guzik, U., Hupert-Kocurek, K., Mazur, A., \& Wojcieszyńska, D. (2013a). Biotransformacja wybranych niesteroidowych leków przeciwzapalnych w środowisku. Bromatologia $i$ Chemia Toksykologiczna, 1, 105-112 (in Polish).

Guzik, U., Hupert-Kocurek, K., \& Wojcieszyńska, D. (2013b). Intradiol dioxygenases - the key enzymes in xenobiotics degradation. In: Chamy, R., \& Rosenkranz, F. (Ed.), Biodegradation of Hazardous and Special Products (pp. 129-153). Rijeka

Guzik, U., Hupert-Kourek, K., \& Wojcieszyńska, D. (2014). Microbial degradation non-steroidal anti-inflammatory drugs. Postepy Mikrobiologii, 53, 61-69 (in Polish).

Halling-Sorensen, B., Nors Nielsen, S., Lanzky, P. F., Ingerslev, F., Holten Lützhof, H. C., \& Jorgensen, S. E. (1998). Occurrence, fate, and effects of pharmaceutical substances in the environment - a review. Chemosphere, 36, 357-393.

Han, S., Choi, K., Kim, J., Ji, K., Kim, S., Aho, B., Yun, J., Choi, K., Khim, J. S., Zhang, X., \& Giesy, J. P. (2010). Endocrine disruption and consequences of chronic exposure to ibuprofen in Japanese medaka Oryzias latipes and freshwater cladocerans Daphnia magna and Moina macrocopa. Aquatic Toxicology, 98, 256-264.

Haribabu, B., Kamath, A. V., \& Vaidyanathan, C. S. (1984). Degradation of substituted benzoic acids by a Micrococcus species. FEMS Microbiology Letters, 21(2), 197-200.

Hart, A., \& Orr, D. L. J. (1975). The degradation of paracetamol (4-hydroxyacetanilide) and other substituted acetanilides by a Penicillium species. Antonie van Leeuwenhoek, 41, 239-247.

Heberer, T. (2002). Occurrence, fate, and removal of pharmaceuticals residues in the aquatic environment: a review of recent research data. Toxicology Letters, 131, 5-17.

Henschel, K. P., Wenzel, A., Diederich, M., \& Fliedner, A. (1997). Environmental hazard assessment of pharmaceuticals. Regulatory Toxicology and Pharmacology, 25, 220-225.

Herd, B., Wynne, H., Wright, P., James, O., \& Woodhouse, K. (1991). The effect of age on glucuronidation and sulphation of paracetamol by human liver fractions. British Journal of Clinical Pharmacology, 32, 768-770.

Hinson, A. H., Roberts, D. W., \& James, L. P. (2010). Mechanisms of acetaminophen-induced liver necrosis. Handbook of Experimental Pharmacology, 196, 369-405.

Hintner, J. P., Lechner, C., Riegert, U., Kuhm, A. E., Storm, T., Reemtsma, T., \& Stolz, A. (2001). Direct ring fission of salicylate by a salicylate 1,2-dioxygenase activity from Pseudaminobacter salicylatoxidans. Journal of Bacteriology, 183(23), 6936-6942.

Huang, H. H., Lin, L. H., Zhang, P., Qi, X. L., \& Zhong, D. F. (2006). Formation of glucoside conjugate of acetaminophen by fungi separated from soil. European Journal of Drug Metabolism and Pharmacokinetics, 31(2), 103-108.

Ingelman-Sundberg, M., Kaur, H., Terelius, Y., Persson, J. O., \& Halliwell, B. (1991). Hydroxylation of salicylate by microsomal fractions and cytochrome P-450. Biochemical Journal, 276, 753-757.

Ishiyama, D., Vujaklija, D., \& Davies, J. (2004). Novel pathway of salicylate degradation by Streptomyces sp. strain WA46. Applied and Environmental Microbiology, 70(3), 1297-1306.

Ivshina, I. B., Rychkova, M. I., Vikhareva, E. V., Chekryshkina, L. A., \& Mishenina, I. I. (2006). Catalysis of the biodegradation of unusable medicines by alkanotrophic Rhodococci. Applied Biochemistry and Microbiology, 42, 392-395.

Iwasaki, Y., Gunji, H., Kino, K., Hattori, T., Ishii, Y., \& Kirimura, K. (2009). Novel metabolic pathway for salicylate biodegradation via phenol in yeast Trichosporon monilifforme. Biodegradation, 21, 557-564.

Jain, R. K., Dreisbach, J. H., \& Spain, J. C. (1994). Biodegradation of $p$-nitrophenol via 1-, 2-, 4-benzenetriol by an Arthrobacter sp. Applied and Environmental Microbiology, 60(8), 30303032.

Jouanneau, Y., Micoud, J., \& Meyer, C. (2007). Purification and characterization of a from Sphingomonas sp. strain CHY-1 three-component salicylate 1-hydroxylase. Applied and Environmental Microbiology, 73(23), 7515-7521.

Katagiri, M., Maeno, H., Yamamoto, S., Hayaishi, O., Kitao, T., \& Oae, S. (1965). Salicylate hydroxylase, a monooxygenase requiring flavin adenine dinucleotide II. The mechanism of salicylate hydroxylation to catechol. The Journal of Biological Chemistry, 240, 3414-3417.

Khan, S. J., \& Ongerth, J. E. (2002). Estimation of pharmaceutical residues in primary and secondary sewage sludge based on quantities of use and fugacity modeling. Water Science and Technology, 46, 105-113.

Kim, J. W., Ishibashi, H., Yamauchi, R., Ichikawa, N., Takao, Y., Hirano, M., Koga, M., \& Arizono, K. (2009). Acute toxicity of pharmaceutical and personal care products on freshwater crustacean Thamnocephalus platyurus and fish Oryzias latipes. Journal of Toxicological Sciences, 342, 227-232.

Kolpin, D. W., Skopiec, M., Meyer, M. T., Furlong, E. T., \& Zaugg, S. D. (2004). Urban contribution of pharmaceuticals and other organic wastewater contaminants to streams during differing flow conditions. Science of the Total Environment, 328, 119-130.

Kolvenbach, B. A., Lenz, M., Benndorf, D., Rapp, E., Fousek, J., Vlcek, C., Schäffer, A., Gabriel, F. L. P., Kohler, H. P. E., \& Corvini, P. F. X. (2011). Purification and characterization of hydroquinone dioxygenase from Sphingomonas sp. strain TTNP3. AMB Express, 1(8), 2-11.

Kühn, R., Pattard, M., Pernak, K. D., \& Winter, A. (1989). Results of the harmful effects of selected water pollutants (anilines, phenols, aliphatic compounds) to Daphnia magna. Water Research, 23(4), 495-499.

Kuspis, D. A., \& Krenzelok, E. P. (1996). What happens to expired medications? A survey of community medication disposal. Veterinary and Human Toxicology, 38(1), 48-49.

Kuswandi, K., \& Roberts, C. F. (1992). Genetic control of the protocatechuic acid pathway in Aspergillus nidulans. Journal of General Microbiology, 138, 817-823.

Lanfranconi, M. P., Christie-Oleza, J. A., Martin-Cardona, C., Suárez-Suárez, L. Y., Lalucat, J., Nogales, B., \& Bosch, R. (2009). Physiological role of NahW, the additional salicylate hydroxylase found in Pseudomonas stutzeri AN10. FEMS Microbiology Letters, 300, 265-272.

Lee, H. B., Peart, T. E., \& Svoboda, M. L. (2005). Determination of endocrine-disrupting phenols, acidic pharmaceuticals, and personal-care products in sewage by solid-phase extraction 
and gas chromatography-mass spectrometry. Journal of Chromatography. A, 1094, 122-129.

Li, J., Ye, Q., \& Gan, J. (2014). Degradation and transformation products of acetaminophen in soil. Water Research, 49, 4452.

Lilius, H., Isomaa, B., \& Holmstrom, T. (1994). A comparison of the toxicity of 50 reference chemicals to freshly isolated rainbow trout hepatocytes and Daphnia magna. Aquatic Toxicology, 30, 47-60.

Lin, A. Y. C., Yu, T. H., \& Lateef, S. K. (2009). Removal of pharmaceuticals in secondary wastewater treatment processes in Taiwan. Journal of Hazardous Materials, 167, 11631169.

Marco-Urrea, E., Pérez-Trujillo, M., Vicent, T., \& Caminal, G. (2009). Ability of white-rot fungi to remove selected pharmaceuticals and identification of degradation products of ibuprofen by Trametes versicolor. Chemosphere, 74, 765772.

Mason, J. R., \& Cammack, R. (1992). The electron transport proteins oh hydroxylating bacterial dioxygenases. Annual Review of Microbiology, 46, 277-305.

Metcalfe, C., Miao, X. S., Hua, W., Letcher, R., \& Servos, M. (2004). Pharmaceuticals in the Canadian environment. In K. Kümmerer (Ed.), Pharmaceuticals in the environment. Sources, fate, effects and risks (pp. 67-90). Berlin: Springer-Verlag.

Middelhoven, W. J. (1993). Catabolism of benzene compounds by ascomycetous and basidiomycetous yeasts and yeast-like fungi. Antonie van Leeuwenhoek, 63, 125-144.

Miyauchi, K., Adachi, Y., Nagata, Y., \& Takagi, M. (1999). Cloning and sequencing of a novel meta-cleavage dioxygenase gene whose product is involved in degradation of gamma-hexachlorocyclohexane in Sphingomonas paucimobilis. Journal of Bacteriology, 181(21), 6712-6719.

Moonen, M. J. H., Synowsky, S. A., van den Berg, W. A. M., Westphal, A. H., Heck, A. J. R., van den Heuvel, R. H. H., Fraaije, M. W., \& van Berkel, W. J. H. (2008). Hydroquinone dioxygenase from Pseudomonas fluorescens ACB: a novel member of the family of nonheme-iron(II)-dependent dioxygenases. Journal of Bacteriology, 190(15), 5199-5209.

Murdoch, R. W., \& Hay, A. G. (2005). Formation of catechols via removal of acid side chains from ibuprofen and related aromatic acids. Applied and Environmental Microbiology, 71(10), 6121-6125.

Murdoch, R. W., \& Hay, A. G. (2013). Genetic and chemical characterization of ibuprofen degradation by Sphingomonas Ibu-2. Microbiology, 159, 621-632.

Murdoch, R. W., \& Hay, A. G. (2015). The biotransformation of ibuprofen to trihydroxyibuprofen in activated sludge and by Variovorax Ibu-1. Biodegradation, 26, 105-113.

Musson, S. E., \& Townsend, T. G. (2009). Pharmaceutical compound content of municipal solid waste. Journal of Hazardous Materials, 162, 730-735.

Nakada, N., Tanishima, T., Shinohara, H., Kiri, K., \& Takada, H. (2006). Pharmaceutical chemicals and endocrine disrupters in municipal wastewater in Tokyo and their removal during activated sludge treatment. Water Research, 40, 3297-3303.

Newton, J. F., Kuo, C. H., Gemborys, M. W., Mudge, G. H., \& Hook, J. B. (1982). Nephrotoxicity of $p$-aminophenol, a metabolite of acetaminophen, in the Fischer 344 rat. Toxicolology and Applied Pharmacology, 65, 336-344.
Pailler, J. Y., Pfister, K. L., Hoffmann, L., \& Guignard, C. (2009). Solid phase extraction coupled to liquid chromatographytandem mass spectrometry analysis of sulfonamides, tetracyclines, analgesics and hormones in surface water and wastewater in Luxembourg. Science of the Total Environment, 40, 4736-4743.

Paterson, J. R., Baxter, G., Dreyer, J. S., Halket, J. M., Flynn, R., \& Lawrence, J. R. (2008). Salicylic acid sans aspirin in animals and man: persistence in fasting and biosynthesis from benzoic acid. Journal of Agricultural and Food Chemistry, 56, 11648-11652.

Penn, C. D., \& Daniel, S. L. (2013). Salicylate degradation by the fungal plant pathogen Sclerotinia sclerotiorum. Current Microbiology, 67(2), 218-225.

Perry, L. L., \& Zylstra, J. (2007). Cloning of a gene cluster involved in the catabolism of $p$-nitrophenol by Arthrobacter sp. strain JS443 and characterization of the $p$-nitrophenol monooxygenase. Journal of Bacteriology, 189(21), 75637572.

Pomati, F., Netting, A. G., Calamari, D., \& Neilan, B. A. (2004). Effects of erythromycin, tetracyclin and ibuprofen on the growth of Synechocystis sp. and Lemna minor. Aquatic Toxicology, 67, 387-396.

Pounds, N., Maclean, S., Webley, M., Pascoe, D., \& Hutchinson, T. (2008). Acute and chronic effects of ibuprofen in the mollusc Planorbis carinatus (Gastropoda: Planorbidae). Ecotoxicology and Environmental Safety, 70, 47-52.

Qi, P. F., Johnston, A., Balcerzak, M., Rocheleau, H., Harris, L. J., Long, X. Y., Wei, Y. M., Zheng, Y. L., \& Ouellet, T. (2012). Effect of salicylic acid on Fusarium graminearum, the major casual agent of fusarium head blight in wheat. Fungal Biology, 116, 413-426.

Quinn, B., Gagne, F., \& Blaise, C. (2008). An investigation into the acute and chronic toxicity of eleven pharmaceuticals (and their solvents) found in wastewater effluent on the cnidarians, Hydra attenuate. Science of the Total Environment, 389, 306-314.

Quintana, J. B., Weiss, S., \& Reemtsma, T. (2005). Pathways and metabolites of microbial degradation of selected acidic pharmaceutical and their occurrence in municipal wastewater treated by a membrane bioreactor. Water Research, 39, 2654-2664.

Rieble, S., Joshi, D. K., \& Gold, M. H. (1994). Purification and characterization of a 1-, 2-, 4-trihydroxybenzene 1,2dioxygenase from the basidiomycete Phanerochaete chrysosporium. Journal of Bacteriology, 176(16), 48384844.

Roberts, P. H., \& Thomas, K. V. (2006). The occurrence of selected pharmaceuticals in wastewater effluent and surface waters of the lower Tyne catchment. Science of the Total Environment, 356, 143-153.

Rodarte-Morales, A. I., Feijoo, G., Moreira, M. T., \& Lema, J. M. (2011). Degradation of selected pharmaceutical and personal care products (PPCPs) by white-rot fungi. World Journal of Microbiology and Biotechnology, 27, 1839-1849.

Rzepa, J. (2009). Oznaczanie leków i pestycydów w wodach powierzchniowych. In B. K. Głoda (Ed.), Postepy Chromatografii (pp. 67-77). Siedlce: Wydawnictwo Akademii Podlaskiej (in Polish).

Salgado, R., Noronha, J. P., Oehmen, A., Carvalho, G., \& Reis, M. A. M. (2010). Analysis of 65 pharmaceuticals and personal 
care products in 5 wastewater treatment plants in Portugal using a simplified analytical methodology. Water Science and Technology, 6212, 2862-2871.

Shamsuzzaman, K., \& Barnsley, E. A. (1974). The regulation of naphthalene oxygenase in Pseudomonads. Biochemical and Biophysical Research Communications, 60, 582-589.

Silva, T. R., Valdman, E., Valdman, B., \& Leite, S. G. F. (2007). Salicylic acid degradation from aqueous solutions using Pseudomonas fluorescens HK44: parameters studies and application tools. Brazilian Journal of Microbiology, 38, 3944.

Song, H., \& Chen, T. S. (2001). p-Aminophenol-induced liver toxicity: tentative evidence of a role for acetaminophen. Journal of Biochemical and Molecular Toxicology, 15, 34 40.

Sosnowska, K., Styszko-Grochowiak, K., \& Gołaś, J. (2009). Leki w środowisku - źródła, przemiany, zagrożenia. IV Krakowska Konferencja Młodych Uczonych (pp. 395-404) (in Polish).

Suzuki, K., Mizuguchi, M., Ohnishi, K., \& Itagaki, E. (1996). Structure of chromosomal DNA coding for Pseudomonas putida S-1 salicylate hydroxylase. Biochimica et Biophysica Acta, 1275, 154-156.

Sze, I. S., \& Dagley, S. (1984). Properties of salicylate hydroxylase and hydroxyquinol 1,2-dioxygenase purified from Trichosporon cutaneum. Journal of Bacteriology, 159(1), 353-359.

Takenaka, S., Okugawa, S., Kadowaki, M., Murakami, S., \& Aoki, K. (2003). Metabolic pathway of 4-aminophenol in Burkholderia sp. strain AK-5 differs from that of aniline and aniline with C-4 substituents. Applied and Environmental Microbiology, 69(9), 5410-5413.

Tauxe-Wuersch, A., de Alencastro, L. F., Grandjean, D., \& Tarradellas, J. (2005). Occurrence of several acidic drugs in sewage treatment plants in Switzerland and risk assessment. Water Research, 39, 1761-1772.

Ternes, T. A. (1998). Occurrence of drugs in German sewage treatment plants and rivers. Water Research, 32, 3245-3260.

Tixier, C., Singer, H. P., Oellers, S., \& Müller, S. R. (2003). Occurrence and fate of carbamazepan, clofibric acid, diclofenac, ibuprofen, ketoprofen and naproxen in surface water. Environmental Science and Technology, 37, 10611068.

Togola, A., \& Budzinski, H. (2008). Multi-residue analysis of pharmaceutical compounds in aqueous samples. Journal of Chromatography A, 1177, 150-158.

Tsikas, D., Trettin, A., Zorner, A. A., \& Gutzki, F. M. (2011). Insource formation of $\mathrm{N}$-acetyl-p-benzoquinone imine (NAPQI), the putatively toxic acetaminophen (paracetamol) metabolite, after derivatization with pentafluorobenzyl bromide and GC-ECNICI-MS analysis. Journal of Chromatography B, 879, 1476-1484.

Verberne, M. C., Verpoorte, R., Bol, J. F., Marcado-Blanco, J., \& Linthorst, H. J. M. (2000). Overproduction of salicylic acid in plants by bacterial transgenes enhances pathogen resistance. Nature Biotechnology, 18, 779-783.

Vieno, N. M., Tuhkanen, T., \& Kronberg, L. (2006). Analysis of neutral and basic pharmaceuticals in sewage treatment plants and in recipient rivers using solid phase extraction and liquid chromatography-tandem mass spectrometry detection. Journal of Chromatography A, 1134, 101-111.

Wang, W. H., \& Lay, J. P. (1989). Fate and effects of salicylic acid compounds in freshwater systems. Ecotoxicology and Environmental Safety, 17(3), 308-316.

Wei, F., Zhou, Q. W., Leng, S. Q., Zhang, L. L., \& Chen, J. M. (2011). Isolation, identification and biodegradation characteristics of a new bacterial strain degrading paracetamol. Chinese Journal of Environmental Science, 32, 1812-1819.

Winkler, M., Lawrence, J. R., \& Neu, T. R. (2001). Selective degradation of ibuprofen and clofibric acid in two model river biofilm systems. Water Research, 3513, 3197-3205.

Wojcieszyńska, D., Greń, I., Hupert-Kocurek, K., \& Guzik, U. (2011). Modulation of FAD-dependent monooxygenase activity from aromatic compounds-degrading Stenotrophomonas maltophilia strain KB2. Acta Biochimica Polonica, 58, 421-426.

Wu, S., Zhang, L., \& Chen, J. (2012). Paracetamol in the environment and its degradation by microorganism. Applied Microbiology and Biotechnology, 96, 875-884.

Zhang, L., Hu, J., Zhu, R., Zhou, Q., \& Chen, J. (2013). Degradation of paracetamol by pure bacterial cultures and their microbial consortium. Applied Microbiology and Biotechnology, 97, 3687-3698.

Zhou, N. Y., Al-Dulayymi, J., Baird, M. S., \& Williams, P. A. (2002). Salicylate 5-hydroxylase from Ralstonia sp. strain U2: a monooxygenase with close relationships to and shared electron transport proteins with naphthalene dioxygenase. Journal of Bacteriology, 184(6), 1547-1555.

Ziylan, A., \& Ince, N. H. (2011). The occurence and fate of antiinflammatory and analgesic pharmaceuticals in sewage and fresh water: treatability by conventional and nonconventional processes. Journal of Hazardous Materials, 187, 24-36.

Zwiener, C., Seeger, S., Glauner, T., \& Frimmel, F. H. (2002). Metabolites from the biodegradation of pharmaceutical residues of ibuprofen in biofilm reactors an batch experiments. Analytical and Bioanalytical Chemistry, 372, 569-575. 